\title{
位相空間，実空間で見た金属人工格子構造
}

中 山 則 昭*

1.はじめに

金属人工格子の構造評価には，ほとんぞすべての研究で X 線回折法が用いられている。X 線回折法は，原子レべ ルに和ける試料の構造を, 位相空間(逆格子空間)に打ける 情報として，比破壊的に調べる方法である．人工格子膜の もつ組成と結晶格子の一次元的な周期的変調に関する知見 を，粉末用のディフラクトメータを用いた場合でも，比較 的容易に得ることがでさる。ただし，薄膜といら試料の形 状のために三次元構造の評価が困難である点, 実空間に沶 ける周期性をもつ成分を抽出した形での情報である点が問 題である.

これらの問題点を補うために，その他多くの構造解析手 法が用いられている。とりわけ，透過電子顕微鏡による断 面構造の直接観察法は, 実空間に拈ける局所構造の評価法 として金属人工格子構造の研究に必須のものとなりつつあ る.ここでは，X線回折法を用いて位相空間で見た金属 人工格子構造と, 透過電子顕徽鏡を用いて実空間でみた金 属人工格子構造について, 研究の現状を紹介する.

\section{X 線回折による構造評価}

X 線回折法を用いて金属人工格子構造を評価する手法 については，いくつかのすぐれた総説がある(1)-(3). 詳細 についてはこれらを参照していただくこととして，まず典 型的な X 線回折パターンについてその特徴を述べ, 次に いくつかの観点から最近の研究を紹介する。

（1）典型的な X 線回折パターン

図 1 は $\mathrm{Au} / \mathrm{Fe}^{(4)}, \mathrm{Au} / \mathrm{Ni}^{(5)(6)}$ および $\mathrm{Mo} / \mathrm{Si}^{(7)}$ 人工格子の $\mathrm{X}$ 線回折パターンである. $\mathrm{X}$ 線の散乱べクトルは膜面に 垂直である、結晶組織という観点から，金属人工格子をい くつかのタイプに分類できるが，これらの人工格子は各々

\section{* 京都大学助教授; 理学部化学教室}

Structures of Metallic Superlattices in Real and Reciprocal Space; Noriaki Nakayama (Department of Chemistry, Faculty of Science, Kyoto University, Kyoto)

Keywords: metallic superlattices, structural characterization, $X$-ray diffraction, transmission electron microscopy, roughness, lattice strain, multilayered films 1992年 5 月 18 日受理
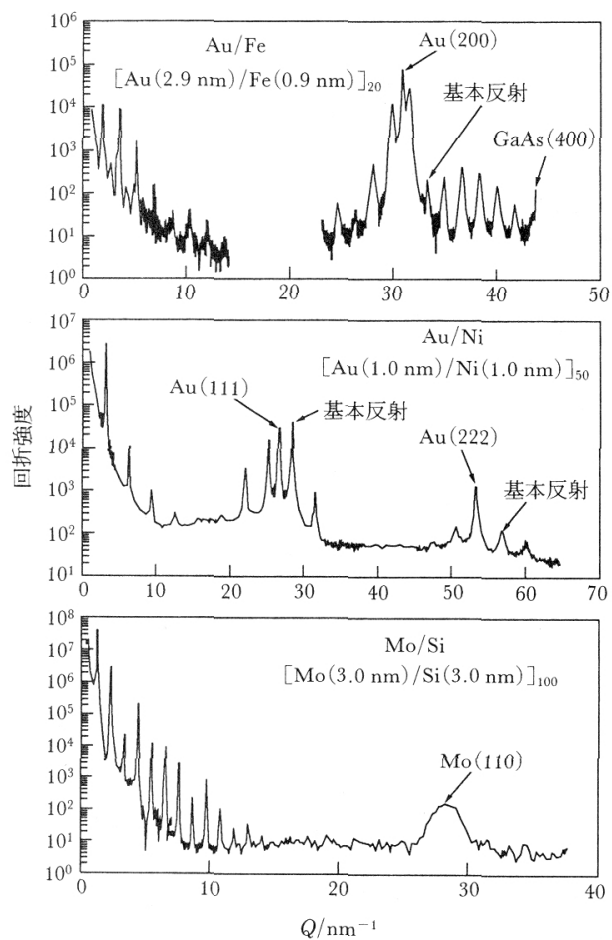

図 1 金属人工格子構造の典型的な $\mathrm{X}$ 線回折パター ン(4)-(7)（散乱べクトル上膜面，横軸は散乱ベク トルの大ささ $Q=4 \pi \sin \theta / \lambda)$.

図 2 のような単結晶人工格子 (タイプ 1), 一軸配向性エピ タキシャル人工格子 (タイプ 2 ), 結晶/非晶質-ノンェピタ キシャル人工格子 (タイプ 3)の典型的な例である.すべて の試料が, 膜面に垂直な方向の周期的な組成変調に由来す る小角域のブラッグピークを示している.

タイプ 1,2 の構造をもつ $\mathrm{Au} / \mathrm{Fe}, \mathrm{Au} / \mathrm{Ni}$ 人工格子では， 中角域にもシャープなブラッグピークがみられる。 それぞ れ下地 $\mathrm{Au}$ 層の配向原子面による $\mathrm{Au}(100)$ および $\mathrm{Au}$ (111) 反射近傍の回折ピークが強い強度を示している. 人工格子中の $\mathrm{Au}$ 層の配向は下地層と同じであり, $\mathrm{Fe}$ お よび Ni の配向原子面は bcc-Fe(100), fcc-Ni(111)である. 規則合金の基本反射々超格子反射に対応する回折反射であ るが, 通常, 基本反射, 衛星反射とよばれる. 基本反射の 位置は, 成長方向の平均格子面間隔 $(8)$ 飞対応する. 回折ピ 一クのシャープさは, 積層方向の原子配列の可干渉性の高 さを示すものでありエピタキシャル成長によるものであ る、タイプ 3 の構造をもつ $\mathrm{Mo} / \mathrm{Si}$ 人工格子では幅の広い 


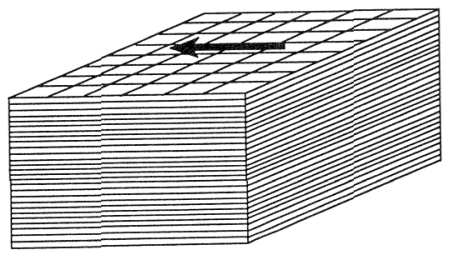

タイプ 1

単結晶人工格子

例 $\mathrm{Au} / \mathrm{Fe}$

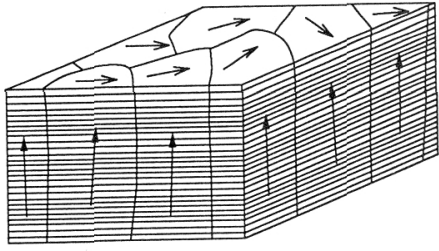

タイプ 2

一軸配向

エピタキシャル

人工格子

例 $\mathrm{Au} / \mathrm{Ni}$

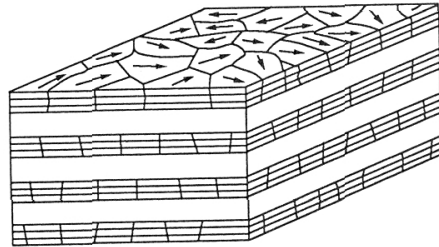

タイプ 3

結晶/非晶質

ノンエピタキシャル

人工格子

例 $\mathrm{Mo} / \mathrm{Si}$
図 2 金属人工格子構造の結晶組織. 他に, 結晶/結 晶-ノンエピタキシャル人工格子(例 $\mathrm{Fe} / \mathrm{Mg}$ ), アモルファス人工格子(例 $\mathrm{Fe} / \mathrm{C}$ )などがある。 矢印结結晶方位を表す。

Mo(110)ピークがみられるだけである. 人工周期のゆら ぎのために，アモルファス $\mathrm{Si}$ 層を隔てた Mo 配向結晶層 間の可干渉性が失われたためである.

三次元位相空間での X 線回折強度分布をみると，タイ プ1の構造とタイプ 2 の構造の違いがわかる.図 3(a), (b) は $\mathrm{Au} / \mathrm{Fe}$ 人工格子の, $\mathrm{Au}(110)$ *逆格子面に扣ける強 度分布である(9). $\mathrm{Au}(002)$ 反射近傍では，基本反射および 衛星反射が湮注等方的な強度分布を示し, 試料が単結晶的 であることを示している。これに対応して，Au(113)反射 の周りにも明瞭な衛星反射が観測されている。図 $3(\mathrm{c})$, (d) は $\mathrm{Au} / \mathrm{Ni}$ 人工格子の結晶配向軸 $\mathrm{Au}[111]^{*}$ *含も任意 の逆格子面内で強度分布である ${ }^{(10)} . \mathrm{Au}(111)$ 反射近傍の 強度分布は，逆格子原点を中心と寸る円弧に沿って広がっ ており，一軸配向構造を構成する結晶子にかなり配向分布 があることを示しているまた，(111)反射と（200）反射 が同一面内で観測され, 一軸配向構造に特有の繊維回折パ ターンとなっていることがわかる。しかし, 衛星反射も観 測されており, 結晶粒内ではエピタキシャル成長が起こっ ていることがわかる。

以上のように，位相空間で見た人工格子構造は様々であ る。図2のような結晶組織の違いに加えて, 膜厚分布, 格子歪, 界面での相互拡散, 界面の凹凸, 界面欠陥, 結晶 配向性のゆらぎ，結晶粒径の分布など様々な構造のゆらぎ が存在しているためである.

\section{（2）層状積層構造の完成度}

小角域のブラッグピークは組成の周期的変調による回折

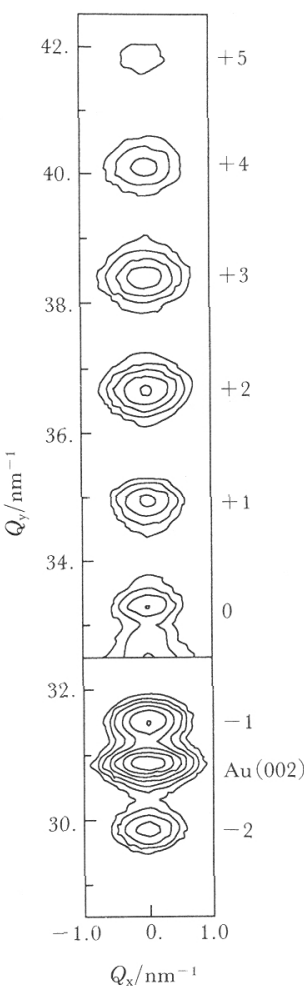

(a)

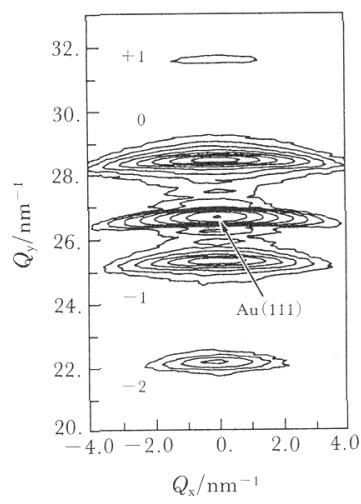

(c)

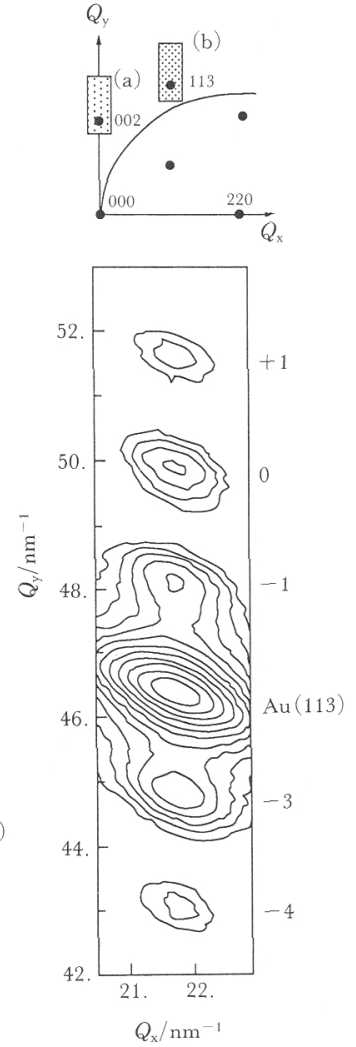

(b)

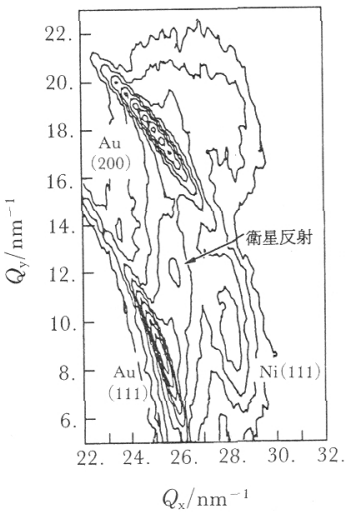

(d)
図 3 位相空間に拈忊る X 線回折強度分布 (対数スケ 一ルの等高図). (a), (b) $\mathrm{Au} / \mathrm{Fe}$ 人工格子 ${ }^{(9)}$. (c), (d) $\mathrm{Au} / \mathrm{Ni}$ 人工格子 ${ }^{(10)}$.

ピークであり，すべての人工格子で観測される，ピークの 位置, 半值幅, 強度比には, 人工周期, 可干渉距離, 界面 にお汓る組成変化の急峻性, A, B 層の膜厚比など多くの 情報が含をれている。乙かし，これらの定量的な評価を行 うためには, 多重散乱や吸収の効果を取り入れた動力学的 回折理論を用いる必要がある(1)(11)。

$\mathrm{Mo} / \mathrm{Si}$ 人工格子など X 線光学素子用の人工格子膜では, 1 次のブラッグピークについて, 回折強度 $I_{\mathrm{obs}}$ の入射 $\mathrm{X}$ 線 
強度 $I_{0}$ に対する比 $R_{\mathrm{obs}}=I_{\mathrm{obs}} / I_{0}$ (反射率) が測定され, 層状 積層構造の完成度が評価されている(11). 反射率の理論値 $\left(R_{\text {calc }}\right)$ は, X 線の波長 $\lambda$ 亿依存する構成元素の光学定数 (複素屈折率)の差によって決まる.人工格子構造の完成度 を知る目安として，次式のような一種の Debye-Waller 因 子が用いられている。

$$
R_{\text {obs }}=R_{\text {cacl }} \exp \left[-\left(4 \pi \frac{\sin \theta}{\lambda} \Delta z\right)^{2}\right]
$$

式中の $\Delta z$ は界面ラフネス因子とよばれている.図 1 中の $\mathrm{Mo} / \mathrm{Si}$ 人工格子の場合には $\Delta z=0.7 \mathrm{~nm}\left(R_{\mathrm{obs}}=52 \%, R_{\text {calc }}\right.$ $=76 \%)$ といら值が得られる. $\Delta z$ の值は, 界面の山凸, 界 面における相互拡散，基板表面の荒さなどの効果をすべて 含む量であるが, 現在のところ人工格子構造の完成度の最 も厳密な判断基準である. 良好な試料では， $\Delta z=0.2 \mathrm{~nm}$ 程度の值が得られている(11). ただし，タイプ2のような モザイク性の高い試料の值については検討を要する。

高次反射も含めた小角 $\mathrm{X}$ 線回折パターンの定量的な解 析は, 今後の重要な研究課題である. 特に, 磁気抵抗効果 に関して問題となっている「界面ラフネス」の本質を明ら かにするためにも詳細な研究が必要である. 最近, 三次元 位相空間における小角ブラッグピークの測定 ${ }^{(12)}$, 人工周 期のゆらぎを考慮した動力学的回折プロファイルの検 討(13)が報告されている。

\section{（3）累積的な構造のゆらぎ}

中角域のブラッグピークについては運動学的回折理論の 範囲内で解析が可能である. 種々のモデル構造について衛 星反射強度の運動学的回折強度が計算され, 実測値と比較 することにより, 相互拡散や格子歪の研究が行われてい る(1)(3). しかし, 定量的な解析を行うためには周期構造の ゆらぎを十分考慮する必要がある。構造のゆらぎが回折パ ターンに及ぼす効果については多数の研究があ る(1)(3)(14)-(16). 人工格子構造のゆらぎには, 離散的な分 布関数で記述できる成分と，連続的な分布関数で記述でき る成分が複合されている。また，式（1）のような DebyeWaller 因子による強度の低下だけでは記述できない，累 積的な効果を示す。

累積的なゆらぎの効果は, 回折反射の半值幅に現われて くる. 図 4 は図 1 中の $\mathrm{Au} / \mathrm{Ni}$ 人工格子の回折パターンに ついて, 各ピークの半值幅 $\Delta Q$ を散乱べクトルの大きさ $Q(=4 \pi \sin \theta / \lambda)$ に対しプロットした図である(10). 理想的 な結晶であれば, 半値幅は結晶の可干渉サイズによって規 定される一定の幅をもつはずである. 実際には， $Q$ の増加 にともなら単調な増大傾向がみられるとともに, 基本反射 を極小値とする変調があることが分かる.

連続的なゆらぎは，格子ミスフィットによる界面近傍の 面間隔の分布やアモルフ, ス層の膜厚分布に起因する. こ れらは, 理想的な構造に対する干渉関数 (ラウエ関数) に作 用し, 散乱ベクトルの絶対值の増大とともに, ピーク強度

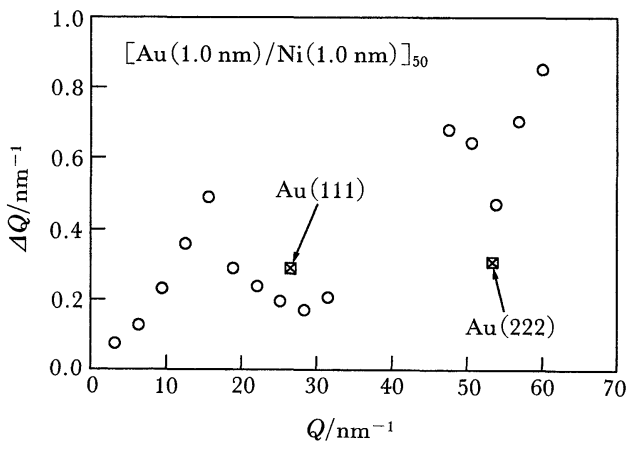

図4 $[\mathrm{Au}(1.0 \mathrm{~nm}) / \mathrm{Ni}(1.0 \mathrm{~nm})]_{50}$ 人工格子の $\mathrm{X}$ 線 回折ピーク幅.

を減少させ，ピーク幅を単調に増大させる，タイプ 3 の 構造をもつ $\mathrm{Mo} / \mathrm{Si}$ 人工格子の回折パターンが典型的な例 であり，Mo(110)反射に対応するような大きさの散乱べ クトルでは干渉関数のピークが消失し，それぞれの Mo 層からの回折反射を単純に足し合わせたものとなってい る.このよらな連続的な分布関数をもつゆらぎの効果は, 結晶性高分子や歪結晶の回折パターンと類似して拈り, 結 晶性高分子の場合には，パラ結晶モデルと呼ばれている.

離散的なゆらぎは, 試料作製中の膜厚制御の不確定性や 薄膜の成長様式に起因する，原子面数の分布である. 層状 エピタキシャル成長が起こる場合であっても，一方の金属 の蒸着終了時に1-2層程度のステップは存在するはずであ る.この上に，他方の金属を堆積させることを繰り返すわ けであるから，結果として試料の断面をみれば図 5 のよう ないわゆるカラム (column) 構造になっていると近似でき る(3). 個々のカラム内の原子面数注は分布があり, また原 子面数のシークェンスには隣り合らカラム間の相関がない ことが分かる.

このような離散的なゆらぎのため, $\mathrm{Au}_{3} \mathrm{Zn}$ などの規則 合金にみられる逆位相境界間隔の混合による不整合構造 や,インターカレイション化合物の積層不整の場合と類似 した回折パターンを示す．離散的なゆらぎに起因する $\mathrm{X}$ 線回折プロファイルの特徵は, 基本反射で最もピーク幅が
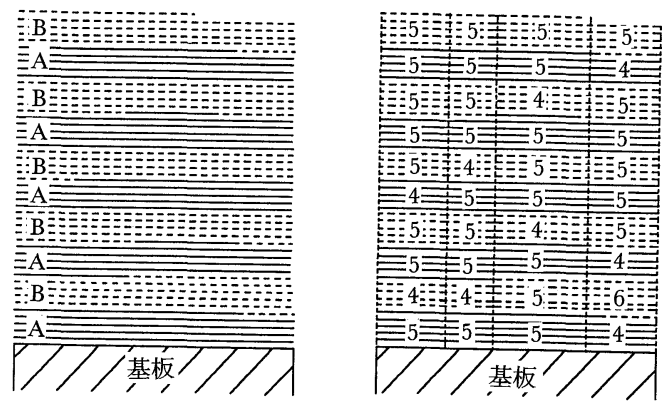

図 5 離散的な分布関数をもつ構造のゆらぎ。(a) 5 原子層 $/ 5$ 原子層人工格子で膜厚誤差が約 $5 \%$ ある場合のモデル構造 ${ }^{(3)}$. (b) (a)のカラム近 似. 
小さく衛星反射の次数の絶対值が增すと幅が大きくなる点 である(3)，実際に，図4のピーク半值幅の $Q$ 依存性はこ の特徵を有している。をた，基本反射の逆格子ベクトルが 超格子反射の逆格子ベクトルと不整合である。汪とんぞの 金属人工格子で, 人工周期 $\Lambda$ と基本反射の面間隔 (平均面 間隔 $\left.d_{\mathrm{AV}}\right)$ との比 $\Lambda / d_{\mathrm{AV}}$ は整数ではない(17)。実際に図 3 の $\mathrm{Au} / \mathrm{Fe}, \mathrm{Au} / \mathrm{Ni}$ 人工格子についてこの值を計算すると 18.4, 8.95となる.

今後, このような累積的なゆらぎの効果や, 結晶子の配 向分布の効果 ${ }^{(18)}$ などが考慮され，X線回折パターンの強 度解析が進められていくと期待される。最近, Fullerton らが，ゆらぎ効果を含む構造精密化法について報告してい $3^{(16)}$.

\section{（4）面内構造と格子歪の評価}

図1のような散乱ベクトルが膜面に垂直な条件での X 線回折実験は，位相空間における一次元的な測定であり， 実空間に批ける膜面に垂直方向の周期性を平均化したもの をみているに過ぎない，金属人工格子構造をさらに詳しく 調べるためには, 図 3 のような三次元位相空間のプロ アイルを解析する必要がある。三次元実空間における金属 人工格子構造で, 重要な因子は膜面内方向の格子周期であ る、特に、二つの金属層がエピタキシャル成長しているタ イプ1あるいは 2 の人工格子構造について, 磁気異方性 や弾性的性質を研究する場合, 格子ミスフィットに起因す る結晶丕の定量的な評価が重要である。面内の格子周期を 測定するためには，X線の散乱べクトルが膜面内にある 配置での測定が必要となる.

図6は厚さ $7 \mu \mathrm{m}$ のポリイミド膜上に蒸着した $\mathrm{Au} /$ $\mathrm{Ni}(111)$ 人工格子の対称透過条件での測定例(6)である。約 13\%の格子ミスフィットがあるため, 回折パターンには 独立した $\mathrm{Au}(220)$ お。さび $\mathrm{Ni}(220)$ 反射が観測されている. しかし，ピーク位置から求めた面間隔はバルクの值とかな り異なって和り，面内方向に大きく歪んでいることが分か る、GaAs 基板をェッチングして同様な測定を行い，Co/ $\mathrm{Cu}$ 人工格子中の $\mathrm{fcc} / \mathrm{hcp}$ 積層不整を検討した報告もあ る(19)，X 線が基板を透過しない場合には，非対称反射法 による測定が可能である. $\mathrm{Au} / \mathrm{Fe}$ 人工格子の場合には, 図 3 の $\mathrm{Au}(113)$ 反射近傍の衛星反射位置から面内格子周 期を知ることができ，下地 $\mathrm{Au}$ 層とほぼ一致する値である ことが分かる。面内エピタキシャル方位は $\mathrm{Au}[220] / /$ $\mathrm{Fe}[200]$, ミスフィットは約0.6\%であり, 整合界面が形 成されているとみなせる。机，Grazing Incidence 法に よる $\mathrm{Ni} / \mathrm{Mo}$ 人工格子の研究も報告されている(20).

\section{3. 透過電子顕微鏡による断面観察}

実空間に捣ける金属人工格子構造を直接観察する方法と して，透過電子顕微鏡法は非常汇重要である。 $0.1 \sim 1 \mu \mathrm{m}$

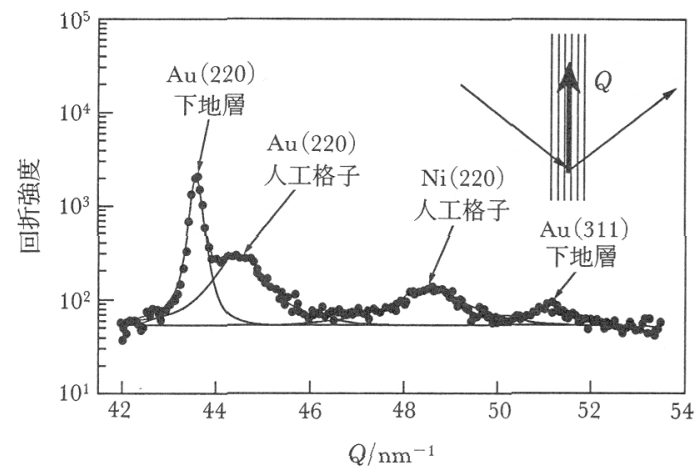

図 6 面内格子周期の測定例(6) (対称透過条件). $[\mathrm{Au}(1.0 \mathrm{~nm}) / \mathrm{Ni}(1.0 \mathrm{~nm})]_{50}$ 人工格子.

程度の領域における平滑性の観察から, 原子配列の直接観 察まで広いダイナミックレンジの構造評価が可能である。 薄膜の断面を観察するための, イオン研磨法あるいは超ミ クロトーム法による検鏡用試料作製の技術が進歩し, 人工 格子構造にとって必須の構造評価手法となりつつある.

まず，積層構造の平滑性を評価できる点が注目される． たと穴ば，基板付近と膜表面付近の平滑性の違いが分か る. 図 7 は $\mathrm{Au} / \mathrm{Ni}$ 人工格子の観察例である ${ }^{(6)}$. 試料の基 板はポリイミド膜であり, 超ミクロトームを用いた切削に より，断面観察用試料が作製されている。この試料では, 下地層として蒸着した膜厚 $25 \mathrm{~nm}$ の $\mathrm{Au}$ バッファ層の近 傍では積層構造はかなり平滑であるが，積層回数が増す と，界面が次第に湾曲化していることが分かる，同様な結 晶配向性と格子ミスフィットを示す $\mathrm{Au} / \mathrm{Co}$ および $\mathrm{Pd} /$ Co 人工格子についてもよく似た観察結果が報告されてい る(21). 面内応力の効果とシャドウイング効果が複合され た結果と考光られる。広い面内領域での平滑性が必要之さ れるX 線光学素子用の金属人工格子では, このよらな低 倍像による積層構造の直接観察が多数報告されている。た とえば, Mo/ $\mathrm{Si}$ 人工格子について, 真空蒸着, 直流スハ

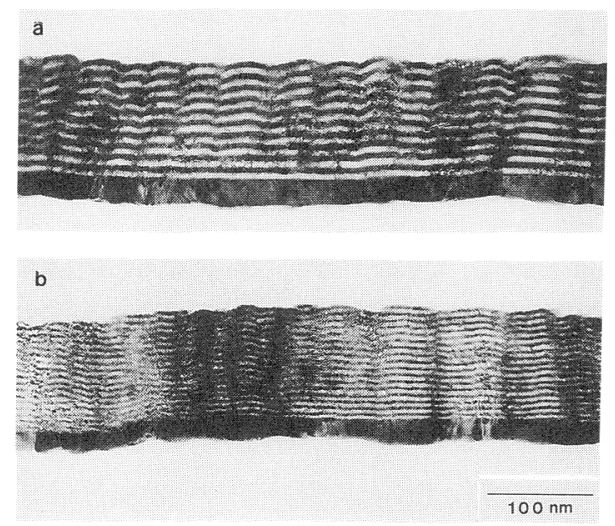

図 $7 \mathrm{Au} / \mathrm{Ni}$ 人工格子断面の透過電子顕微鏡像 ${ }^{(5)}$.

(a) $[\mathrm{Au}(5.3 \mathrm{~nm}) / \mathrm{Ni}(5.3 \mathrm{~nm})]_{10}$.

(b) $[\mathrm{Au}(3.0 \mathrm{~nm}) / \mathrm{Ni}(3.0 \mathrm{~nm})]_{17}$. 

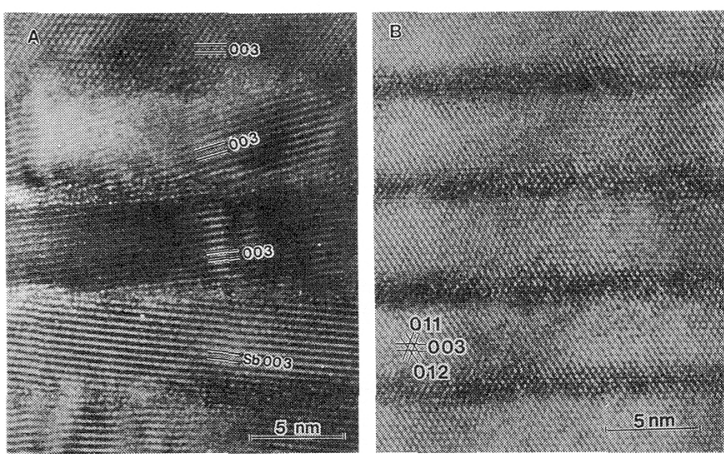

図 $8[\mathrm{Cr}(0.2 \mathrm{~nm}) / \mathrm{Sb}(5.0 \mathrm{~nm})]$ 人工格子断面の透過 電子顕微鏡像 ${ }^{(25)}$ 。（a）基板温度 $223 \mathrm{~K}$ ，(b) 基板温度 $363 \mathrm{~K}$.

ッタ法，高周波スパッタ法およびイオンビームスパッタ法 を用いて試料を作製し，平滑性の違いを明らかにした報告 などがある(22)

原子レベルの構造については, ミスフィット転位 ${ }^{(21)}$, 界面の格子面間隔 ${ }^{(23)}$, 積層不整 ${ }^{(21)}$, 界面反応生成 物 (24) (25)などの高分解能格子像観察が報告されている。図 8 は異なる基板温度で作製した $[\mathrm{Cr}(0.2 \mathrm{~nm}) / \mathrm{Sb}(5.0 \mathrm{~nm})]$ 人工格子の観察例である(25)。基板温度 $223 \mathrm{~K}$ の場合には エピタキシャル人工格子は生成されず， $\mathrm{Sb}(003)$ 格子縞の 方向がそろっていない。これに対し基板温度 $363 \mathrm{~K}$ の場 合には，界面反応によって生成された $\mathrm{CrSb}$ 層が $\mathrm{Sb}$ 層と に整合エピタキシャル成長した結果，隣り合ら $\mathrm{Sb}$ 層ぞら しがコヒーレントにつながっていることが明らかにされて いる. 今後, 高分解能観察による原子レベルでの観察が数 多く報告され，X 線回折法の結果と比較対比されること により，人工格子中の界面での原子配列が解明されて行く もの之期待される.

\section{4. ま め}

以上，位相空間で金属人工格子構造をみるための X 線 回折法による研究と，実空間で金属人工格子構造をみるた めの透過電子顕微鏡法による研究について述べた。これら の構造評価法では, 解析の定量性の向上が今後の検討課題 である、その他，今後重要であると考えられる手法がいく つかある、まず，X線吸収端微細構造による局所構造の 解析がある。特定元素の周りの局所的な構造環境を試料全 体について評価できる点が特徵である。局所情報に弱い $\mathrm{X}$ 線回折之，局所のみの観察で試料全体の情報が得にく い透過電子顕微鏡法の橋渡しが期待される(26). 実空間に 扣ける構造評価法としては，走査トンネル顕微鏡による破 断面の観察が期待される(27)。 また，ラザフォード後方散 乱法による試料の組成分析も，X 線回折による定量解析 を行ら際に重要である(28).
本稿をまとめるにあたり，研究成果を引用させていただ いた京大化研 新庄輝也教授, 東大物性研 藤井保彦教授を はじめとする共同研究者の方々汇感謝の意を表します。

\section{文献}

(1) Y. Fujii: Metallic Superlattices: Artificially Structured Materials, Ed. by T. Shinjo and T. Takada, Elsevier Sci. Pub., Amsterdam, (1987), 33.

（2）藤井保彦：日本金属学会会報，27(1988), 173 .

(3) D. B. McWhan: Physics, Fabrication and Application of Multilayered Structure, Ed. by P. Dhez and C. Weisbuch, Plenum, (1988), 67.

(4) T. Okuyama: Jpn. J. Appl. Phys., 30 (1991), 2053.

( 5 ) H. Dohnomae, N. Nakayama and T. Shinjo: Mater. Trans., JIM, 31(1990), 615.

(6) H. Konishi, Y. Fujii, N. Hamaya, H. Kawada, Y. Ohishi, N. Nakayama, L. Wu, H. Dohnomae, T. Shinjo and T. Matsushita: Rev. Sci. Instrum., 63 (1992), 1035.

( 7 ) H. Nakajima, K. Fujimori and M. Koiwa: J. Appl. Phys., $63(1988), 1046$.

(8) 例えば, P. Bisanti, M. B. Brodsky, G. P. Felcher, M. Grimsditch and L. R. Sill: Phys. Rev., B35(1987), 7813.

（9）中山則昭, 奥山哲雄, 新庄輝也：日本結晶学会年会講演 予稿集，(1991), 92.

(10) N. Nakayama, L. Wu, H. Dohnomae and T. Shinjo: private communication

(11) 例光ば, E. Spiller: Physics, Fabrication and Application off Mulitilayered Structure, Ed. by P. Dhez and C. Weisbuch, Plenum Press, (1988), 67; 山下広順：日本物 理学会誌, 47(1992), 293.

(12) J. B. Kortright: J. Appl. Phys., 70 (1991), 3620.

(13) H. Vanderstraeten, D. Neerinck, K. Temst, Y. Bruynseraede, E. E. Fullerton and I. K. Schuller: J. Appl. Cryst., 24 (1991), 571.

(14) D. Neerinck, H. Vanderstraeten, L. Stockman, J-p. Locquet, Y. Bruynseraede and I. K. Schuller: J. Phys: Condens. Matter, 2 (1990), 4111.

(15) J. -P. Locquet, D. Neerinck, L. Stockman, Y. Bruynseraede and I. K. Schuller: Phys. Rev., B39 (1989), 13338.

(16) E. E. Fullerton, I. K. Schuller, H. Vanderstraeten and Y. Bruynseraede: Phys. Rev., B45 (1992), 9292.

(17) B. Window: J. Appl. Phys., 63 (1988), 1080.

(18) I. Moritani, N. Nakayama and T. Shinjo: J. Phys. Condens. Matter., 2(1990), 9717.

(19) F. J. Lamelas, C. H. Lee, H. He, W. Vavra and R. Clarke: Phys. Rev., B40(1989), 5837.

(20) J. A. Bain, L. J. Chyung, S. Brennan and B. M. Clemens: Phys. Rev., B44 (1991), 1184.

(21) F. Hakkens, W. Coene and F. J. A. den Broeder: Mat. Res. Soc. Symp. Proc., 231 (1992), 397.

(22) S. Ogura, M. Niibe, Y. Watanabe, M. Hayashida and T. Iizuka: Proc. SPIE, 984(1988), 140.

(23) A. F. Jankowski: J. Appl. Phys., 71 (1992), 1782.

(24) N. Nakayama, I. Moritani, T. Shinjo, A. Ishizaki and K. Hajimoto: Phil. Mag., A59(1989), 547.

(25) H. Dohnomae, K. Shintaku, N. Nakayama and T. Shinjo: submitted to Appl. Surf. Sci.

(26) S. M. Heald: Rev. Sci. Instrum., 63(1992), 873.

(27) T. Kato, F. Osaka and I. Tanaka: Jpn. J. Appl. Phys., 28(1989), 1050.

(28) W. R. Bennett, J. A. Leavitt and C. M. Falco: Phys. Rev., B35 (1987), 4199. 